\title{
Nanomole per Minute
}

National Cancer Institute

\section{Source}

National Cancer Institute. Nanomole per Minute. NCI Thesaurus. Code C85758.

Nanomoles per minute. 